\title{
Communication \\ DNA-Based Assembly of Quantum Dots into Dimers and Helices
}

\author{
Tao Zhang *,+(i) and Tim Liedl
}

Faculty of Physics and Center for Nanoscience (CeNS), Ludwig-Maximilians-Universität München (LMU),

D-80539 Munich, Germany; tim.liedl@physik.lmu.de

* Correspondence: tao.zhang@is.mpg.de; Tel.: +49-711-689-1841

+ Current address: Max-Planck-Institute for Intelligent Systems, D-70569 Stuttgart, Germany.

Received: 30 January 2019; Accepted: 21 February 2019; Published: 2 March 2019

\begin{abstract}
Owing to their unique optical properties, colloidal quantum dots (QDs) have attracted much attention as versatile fluorescent markers with broad biological and physical applications. On the other hand, DNA-based assembly has proven to be a powerful bottom-up approach to create designer nanoscale objects and to use these objects for the site-directed arrangement of guest components. To achieve good colloidal stability and accurate positioning of QDs on DNA templates, robust QD surface functionalization is crucial. Here, we present a simple and reliable conjugation method for the direct attachment of DNA molecules to QDs. Phosphorothiolated regions of chimera oligonucleotides are attached and incorporated into a ZnS layer freshly growing in situ on QDs that were rendered water soluble with hydrophilic ligands in a prior step. The reaction can be completed in a $2 \mathrm{~mL}$ plastic tube without any special equipment. The utility of these DNA-labeled QDs is demonstrated via prototypical assemblies such as QDs dimers with various spacings and chiral helical architectures.
\end{abstract}

Keywords: quantum dots; DNA-QDs conjugation; DNA nanotechnology

\section{Introduction}

Colloidal semiconductor quantum dots (QDs), in comparison to organic fluorophores, offer several advantages, such as a broader excitation spectra, a narrow and sharply defined emission peak, a longer fluorescence lifetime, orders of magnitude higher photochemical stability, and high resistance to photobleaching [1]. QDs are often considered to be artificial atoms and, as a result of the quantum confinement effect, possess exceptional tunability of their electronic energy levels [2-5]. Their excitation recombination energies, recombination rates, and the spatial distributions of electrons and holes can be carefully engineered by controlling the size, shape, crystal structure, and composition of the constituent materials. Despite their potential toxicity $[6,7]$ and slow diffusion due to their large physical sizes compared with organic dyes [8], QDs have received considerable attention for various applications in bio-imaging, real-time tracking, and therapeutic drug delivery [9-11]. Moreover, their unique optical properties also make QDs appealing candidates for light-emitting diodes, photovoltaic cells, quantum computation, and communications, and they have recently entered the market of consumer electronics [12,13].

To control the photophysical properties of QDs, the primary chemical interest is to master their synthesis to obtain nanocrystals with defined shapes and sizes. As the crystal structure of an individual QD is crucial for its intrinsic properties, a rigorous understanding of the structure-property relationship will allow researchers to optimize QD synthesis and to obtain designed photonic properties in an iterative manner. In fact, ever since the groundbreaking work of growing CdSe nanocrystals in trioctylphosphine oxide (TOPO) was achieved [14], the chemistry at the organic-inorganic interface 
has been more and more regulated during QD synthesis and has reached exquisite control today. This is achieved by tuning numerous parameters, such as precursors, organic surfactants, solvents, and temperature or through cation exchange reactions [15]. Spherical QDs, one-dimensional (1D) quantum nanorods (NRs), and intricately branched nanocrystals have been successfully synthesized with high uniformity through kinetic shape control [16-19]. Another way to modify the physical properties of QDs is to organize them in defined geometries where the local electromagnetic environment can be determined by neighboring QDs or by other means, e.g., metallic nanoparticles. Assembled QDs thereby enable a range of studies, such as plasmon-exciton interactions for excitation and emission enhancement, carrier-carrier interactions, and nanoscale spin and energy transfers [20-23].

To develop practical approaches for precise QD placement, various paths can be followed. Through lithography or slow solvent evaporation, large-scale QD arrays or densely packed QD lattices can be created $[24,25]$. However, with respect to these processes, there remain challenges to generating finite-sized assemblies containing discrete numbers of components with controlled particle-particle spacings. Alternatively, bottom-up self-assembly positions individual nanoparticles in space via a spontaneous process without the requirement of cumbersome equipment. During self-assembly, the surface ligands, temperature, and ionic strength of the solvent and multiple other parameters define the inter-particle interactions. In principle, any kind of interactive molecular pairs can be implemented to promote nanoparticle assembly, as long as the molecules of interest can be attached to the nanoparticles to thus translate the molecular interactions to the interactions between the coated nanoparticles. Through this approach, higher order nanoparticle assembly has been demonstrated by using ligands such as small molecules [26], polymers [27,28], peptides [29], proteins [30], and DNA [31-33]. In particular, due to the simple rule of base pair complementarity and tunable hybridization strength via temperature, solvent conditions (such as salt concentrations, $\mathrm{pH}$, etc.), strand lengths and sequences, DNA allows researchers to introduce highly specific, orthogonal designs of multiple ligands. Furthermore, DNA nanotechnology has the capacity to fold discrete nanostructures of intricate shapes with high yields, thus serving as a perfect template for QD assembly [34].

Generally speaking, in this work, we address a threefold challenge for DNA-based QD assembly: i) to reliably attach DNA to QDs, ii) to obtain designed QD assemblies with high yields, and iii) to characterize optical signatures. Previous endeavors involving DNA-QD conjugation include direct conjugation with thiolated DNA [35], phosphorothiolated DNA oligonucleotides (PTO-DNA) [36,37] or amino-DNA through heterolinkers [38], indirect conjugation via a streptavidin-biotin linkage [39,40], silica or polymer shells providing chemical groups for DNA coupling [41-43], and DNA attachment in situ during QD synthesis [44-46]. While ligand exchange usually leads to decreased fluorescence efficiencies and a propensity to precipitation, amphiphilic polymer (Figure S1) or protein encapsulation and using silicon shells leads to an additional, often thick, shell on the QDs, which in turn inhibits distance-sensitive energy and information transfer. In contrast, in situ modification realizes the DNA-QD conjugation during QD (CdTe, CdTe/ZnS) growth using thiolated DNA or PTO-DNA as surface capping ligands. The synthesized QDs thus bear the DNA ligands primarily without any intermediate linker, potentially allowing for small particle-particle distances. QDs with such modifications have already been assembled in a site-specific manner, including the formation of heterostructures of gold nanoparticles (AuNPs) with QDs [47]. So far, however, DNA-QD in situ modification has started from ion precursors and thus necessitated the use of a wet chemistry laboratory to accomplish the QD synthesis or shell growth. Here, we report an in situ surface functionalization method to attach PTO-DNA strands onto ZnS-shelled QDs in the presence of zinc ions and 3-mercaptopropionic acid (MPA) ligands. Our method can be performed without any special equipment in a $2 \mathrm{~mL}$ plastic tube. We further demonstrate the distance-controlled assembly of QD dimers and chiral helical arrangements on DNA origami templates. 


\section{Materials and Methods}

\subsection{Quantum Dots}

MPA-stabilized core/shell quantum dots CdSe/CdS/ZnS (emission peak at $640 \mathrm{~nm}$ [48]) and CdSeS/ZnS (emission peak at 540 or 575 nm; Cytodiagnostics, Burlington, ON, Canada) were used as received. The concentration was estimated from the mass concentration. Zinc nitrate, MPA, and other materials were purchased from Sigma Aldrich (Taufkichen, Germany) unless stated otherwise.

\subsection{DNA}

Phosphorothiolated DNA oligonucleotides (PTO-DNA) (sequence: $\mathrm{g}_{9}-\mathrm{T}_{9}$, phosphorothiolated 9 guanine bases and native 9 thymine bases) were purchased from Eurofins Genomics (Ebersberg, Germany). Scaffold p7249 and p7560 were produced in house via phage-infected Escherichia coli cell culturing as described elsewhere [49]. Staple strands for DNA origami folding were synthesized by Eurofins Genomics.

\subsection{DNA-QD Modification}

The conjugation method was adopted from previous reports (Figure 1) [46,50]. Briefly, $100 \mu \mathrm{L}$ of $100 \mathrm{nM}$ MPA-capped, ZnS-shelled QDs (in water) were mixed with $20 \mu \mathrm{L}$ of $100 \mu \mathrm{M}$ PTO-DNA

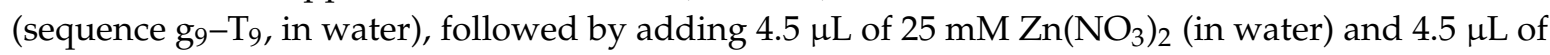
$50 \mathrm{mM}$ MPA (in water). The mixture was gently shaken before adding $4 \mu \mathrm{L}$ of $1 \mathrm{M} \mathrm{NaOH}$ (in water) to deprotonize the MPA ligands. Thereafter, the mixture was incubated at $90{ }^{\circ} \mathrm{C}$ for different times. DNA-conjugated QDs were purified using $100 \mathrm{kDa}$ cut-off Amicon filters at a speed of $4600 \mathrm{~g}$ for $2 \mathrm{~min}$, followed by an additional 3 rounds of washing by adding $500 \mu \mathrm{L}$ of water each time, followed by spinning at $4600 \mathrm{~g}$.

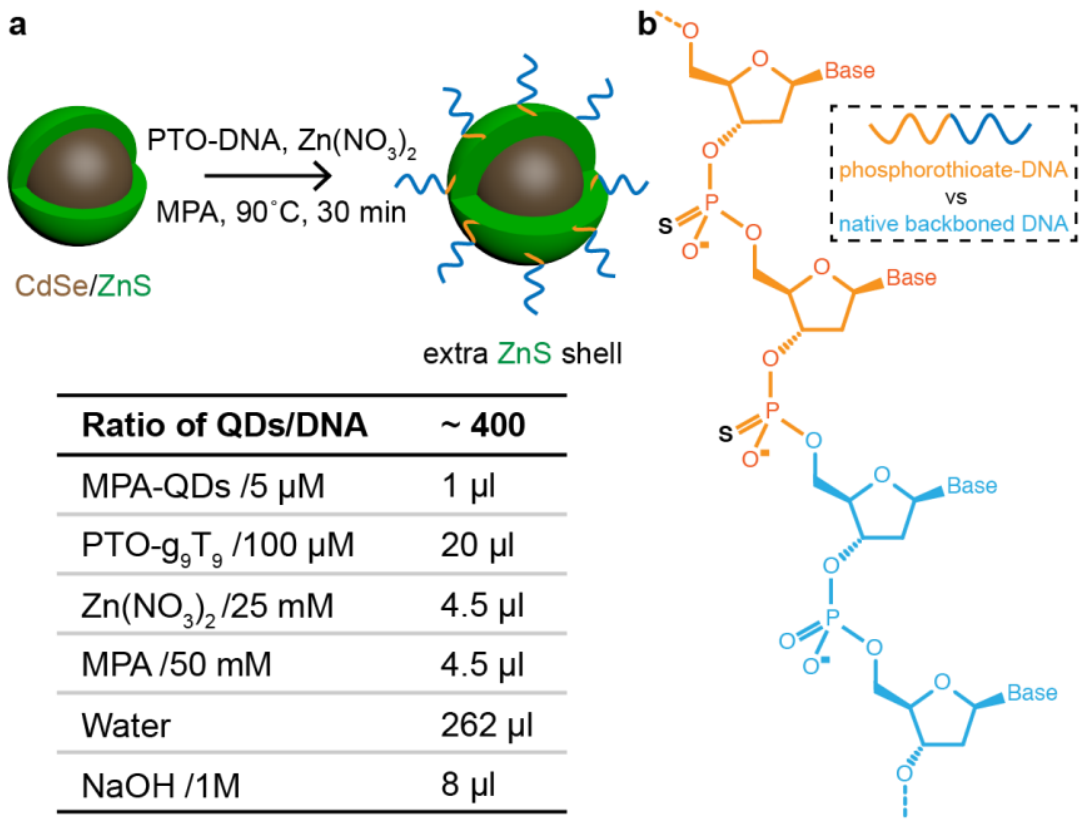

Figure 1. Schematic illustration of incorporating phosphorothiolated DNA oligonucleotides (PTO-DNA) into a freshly-grown ZnS shell. (a) PTO-DNA in situ attachment to the extra layers of $\mathrm{ZnS}$ shell and a table showing the different precursors; (b) Molecular structure of a chimera DNA strand showing two phosphorothiolated backbone bond (orange section) and one native bond (blue section). The black "S" highlights the atomic difference of the upper phosphate link. MPA: 3-mercaptopropionic acid. 


\subsection{DNA Origami}

The one-layer sheet and the 24-helix bundle (24-HB, with DNA duplex stacked in a honeycomb lattice) used in this study were designed with caDNAno [51]. DNA staple strands (100 $\mathrm{nM}$ each) and the circular DNA scaffold strand (10 nM p7249 for one-layer sheet or $10 \mathrm{nM} \mathrm{p7560} \mathrm{for} \mathrm{24-HB)} \mathrm{in} 1 \times$ TE- $\mathrm{Mg}^{2+}$ buffer (10 $\mathrm{mM}$ Tris base, $1 \mathrm{mM}$ Ethylenediaminetetraacetic acid (EDTA), $14 \mathrm{mM} \mathrm{MgCl}$ ) was thermally annealed from 65 to $4{ }^{\circ} \mathrm{C}$ over $27 \mathrm{~h}\left(15 \mathrm{~min}\right.$ at $65^{\circ} \mathrm{C}$, cooling to $58^{\circ} \mathrm{C}$ with a cooling rate of $-1{ }^{\circ} \mathrm{C}$ per $5 \mathrm{~min}$, from 58 to $35^{\circ} \mathrm{C}$ with a rate of $-1{ }^{\circ} \mathrm{C}$ per $1 \mathrm{~h}$, and from 35 to $4{ }^{\circ} \mathrm{C}$ with a rate of $-1{ }^{\circ} \mathrm{C}$ per $5 \mathrm{~min}$ ). The folded DNA nanostructures were purified from excess DNA staple strands by agarose gel electrophoresis $(0.7 \%$ agarose in $1 \times$ TAE ( $40 \mathrm{mM}$ Tris base, $20 \mathrm{mM}$ Acetic acid, $1 \mathrm{mM}$ EDTA), $11 \mathrm{mM} \mathrm{MgCl} 2$ buffer; $6.5 \mathrm{~V} / \mathrm{cm}$ for $2 \mathrm{~h}$ ) stained with $1 \times$ Sybr Safe (Thermo Fisher Scientific, Dreieich, Germany) in ice water baths. The origami samples were extracted from the corresponding gel bands by excision of the bands and recovery of the products by squeezing the gel pieces between two glass slides and collecting the resulting liquid droplet with a pipette.

\subsection{QD Assembly on DNA Nanostructures}

For both dimer and helical assembly, DNA origami together with a 10-time excess of QDs per site were mixed and incubated at room temperature $\left(25^{\circ} \mathrm{C}\right)$ for $6 \mathrm{~h}$. The QD-DNA nanostructure assemblies were purified from excessive QDs and clusters via agarose gel electrophoresis. The gel electrophoresis method was carried out as described above but without staining the gel, as the QDs are bright enough to serve as a reference.

\subsection{TEM Imaging}

Transmission electron microscopy (TEM) imaging of the DNA origami and QD-DNA origami assemblies was carried out using a JEM-1011 transmission electron microscope (JEOL, Tokyo, Japan) operating at $80 \mathrm{kV}$. Typically, $10 \mu \mathrm{L}$ of sample volume was deposited onto Argon plasma-treated formvar/carbon-coated (copper mesh) grids (Ted Pella, Inc., Redding, CA, USA; prod no. 01753-f) for up to $1 \mathrm{~min}$. The drop was then removed using filer paper, and the grid was washed and stained with $2 \%$ aqueous uranyl formate solution.

\section{Results}

We first analyzed the sizes of the CdSeS/ZnS QDs with their additionally grown ZnS shell plus the incorporated DNA strands depending on the incubation time (cf. protocol above). The contrast of the unstained samples was sufficient to allow the measurement of the sizes of the particles. QDs incubated for a longer time showed increased nanoparticle sizes in comparison with the original QDs due to the newly grown ZnS shell (Figure 2a). While the QDs grown for $15 \mathrm{~min}$ have a diameter of $6.0 \pm 1.6 \mathrm{~nm}$ (standard deviation), all the other samples are larger. These results agree well with a previous report [52]. Interestingly, the average sizes of the particles after an incubation time of 30, 45, and $60 \mathrm{~min}$ are very similar $(7.0 \pm 1.8 \mathrm{~nm}, 7.1 \pm 1.8 \mathrm{~nm}$, and $7.0 \pm 1.7 \mathrm{~nm}$, respectively). This could be a result of the depletion of the growing materials and a completion for the DNA attachment. Figure $2 \mathrm{~b}$ shows TEM images of dispersed DNA-conjugated QDs incubated at $90{ }^{\circ} \mathrm{C}$ for $30 \mathrm{~min}$ in water. More TEM images and analytical methods are included in the supporting information (Figures S2-S4). Agarose gel electrophoresis (Figure S5) reveals that only DNA-conjugated particles enter the gel. With increasing incubation time, a decreased brightness of the corresponding bands is observed, indicating the reduction of the optical stability of the QDs. 

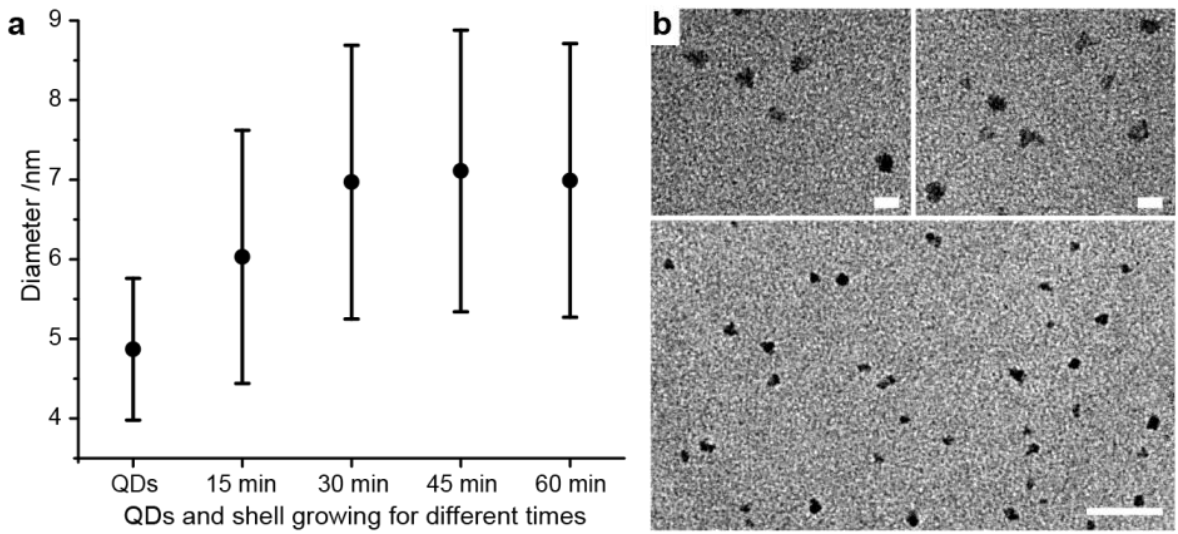

Figure 2. (a) Size analysis for quantum dots (QDs) without conjugation shells and QDs incubated with DNA, $\mathrm{Zn}\left(\mathrm{NO}_{3}\right)_{2}$, and 3-mercaptopropionic acid (MPA) for different times; (b) Transmission electron microscopy images for PTO-DNA-modified CdSeS/ZnS after 30-min incubation at $90^{\circ} \mathrm{C}$. Scale bars: $10 \mathrm{~nm}$ (upper panels) and $50 \mathrm{~nm}$ (lower panel). TEM images for QDs incubated for different times are included in the supporting information (Figures S2-S4).

We then tested the assembly of DNA-conjugated QDs on DNA structures. We first prepared dimers of CdSe/CdS/ZnS QDs with various spacings on a one-layer DNA origami template. As shown in Figure 3a-c, the QDs assembled in dimers with designed spacings of 12, 25, and $50 \mathrm{~nm}$ (Figure S6). In the TEM images, the rectangular DNA origami templates are clearly visible despite the low contrast provided by the single layer of double-stranded DNA. The darker spots indicate the QDs, which were located at the designated sites and were individually distinguishable in the cases of the larger particle distances. The average spacing was measured to be $12 \pm 5 \mathrm{~nm}, 24 \pm 7 \mathrm{~nm}$, and $53 \pm 9 \mathrm{~nm}$, respectively. The large variations are a result of occasional bending and twisting of the single-layered DNA origami templates, which lack rigidity [53]. We found that the dimer assembly yield critically depends on the distance between the QDs. Due to the increased steric and electrostatic repulsion forces between the particles when forced close to each other, the binding efficiency of the dimer structures was found to be $\sim 66 \%$ for the $50 \mathrm{~nm}$ spacing, $\sim 56 \%$ for the $25 \mathrm{~nm}$ samples, and only $\sim 30 \%$ for the $12 \mathrm{~nm}$ spacing. The attachment yield per site reached a yield of $82 \%$ per site, which is below that of previously reported methods $[40,46]$, due to the following disadvantages. Firstly, particles sometimes bind non-specifically to the scaffold loops that connect the neighboring helices at their ends, resulting in trimer assemblies. Another reason for the relatively low attachment yields-in particular if compared with gold particle attachment yields, which can reach 99\% [54] - is the formation of QD clusters in the presence of magnesium ions. As mentioned above, for the short distances, it was difficult to distinguish the individual QDs, especially after the staining of the samples with uranyl materials. The numbers are given for CdSe/CdS/ZnS QDs. Other materials or different core/shell designs of the QDs can further influence the assembly yield.

To determine the influences of surface modification and DNA origami assembly on the optical properties of the QDs, blinking behavior was studied using a fluorescence microscope (Olympus, Tokyo, Japan). The QD samples were spread on glass slides and fluorescence movies were collected with an iXon EMCCD camera (Andor Technology, Belfast, UK) from dried samples. For both, individual DNA-modified QDs and QDs dimer assemblies, switching between bright (ON) and dark (OFF) states on multiple time scales was observed, which indicates typical behavior of fluorescent quantum dots [55] (Figure 3d and Figures S7 and S8). Dimers also exhibited the expected three-state behavior; however, the time traces of the QD dimers showed such fast bleaching (within several tens of seconds and less) that further analysis of the traces, e.g., testing the influence of the inter-particle distance on the blinking rates, yielded ambiguous results. This result indicates a significant loss of optical stability after the assembly and purification processes and is in line with the observation of the reduced brightness of the particles after conjugation (Figure S5). 

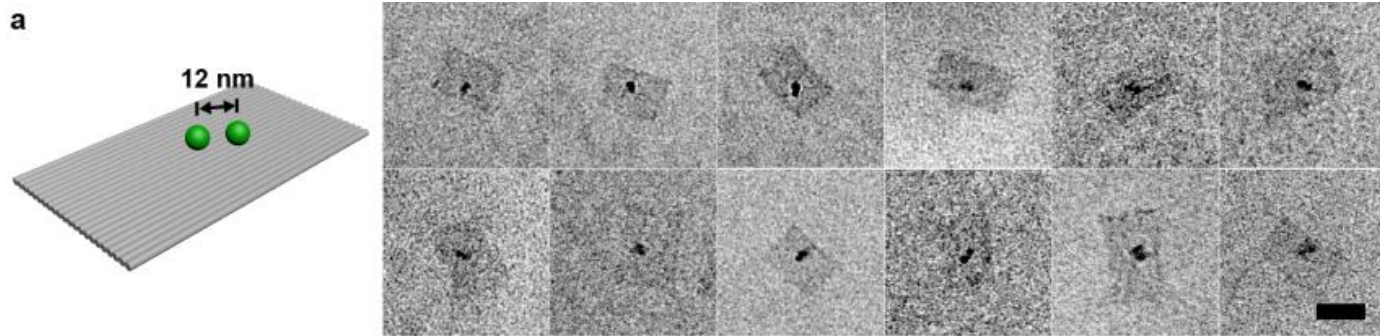

b
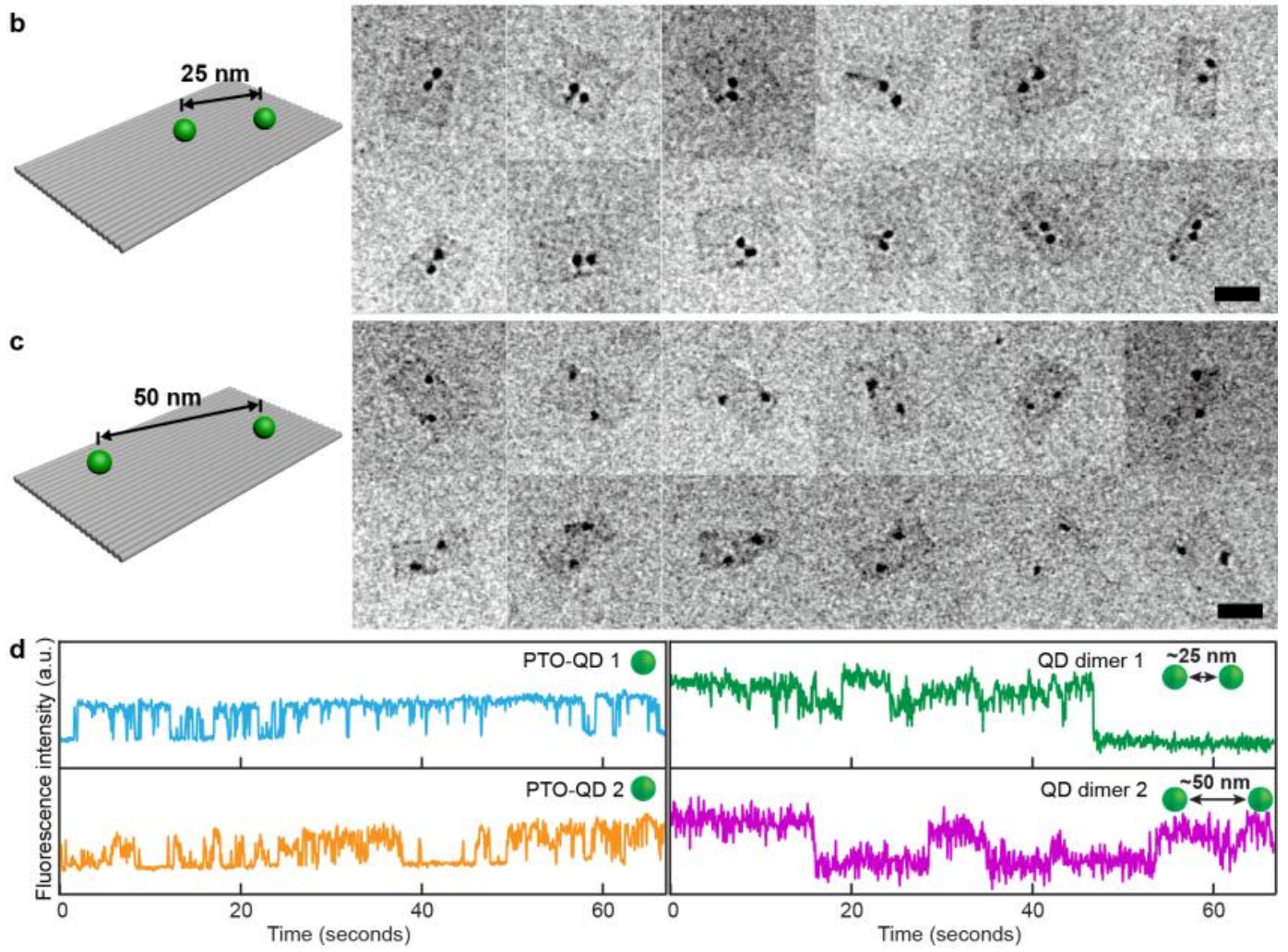

Figure 3. Assembly scheme and corresponding transmission electron microscopy images of $\mathrm{CdSe} / \mathrm{CdS} / \mathrm{ZnS}$ quantum dots assembled into dimers with different distances on one-layer rectangular DNA origami templates. (a) QD dimer with $12 \mathrm{~nm}$ inter-particle spacing; (b) $25 \mathrm{~nm}$ inter-particle spacing; (c) $50 \mathrm{~nm}$ inter-particle spacing. Scale bars: $50 \mathrm{~nm}$; (d) Fluorescence intensity traces of various QD samples: individual PTO-DNA modified QDs (blue and orange), QD dimers with $25 \mathrm{~nm}$ (green) and $50 \mathrm{~nm}$ (purple) spacings.

Finally, we applied our method to build higher order QD assemblies. Figure 4 shows the chiral arrangement of fluorescent colloidal QDs on a 24-HB (Figure S9), which were here left-handed helices, which in principle could give rise to polarization specific absorption and emission. We did not observe these effects, which we attribute to the still relatively large distance between the particles (the designed center-to-center distance was $\sim 11 \mathrm{~nm}$ [54]) and the low concentration (below $50 \mathrm{pM}$ ) of our assembled helices. Nevertheless, such systems could open new perspectives for luminescence-based detection and sensing. 

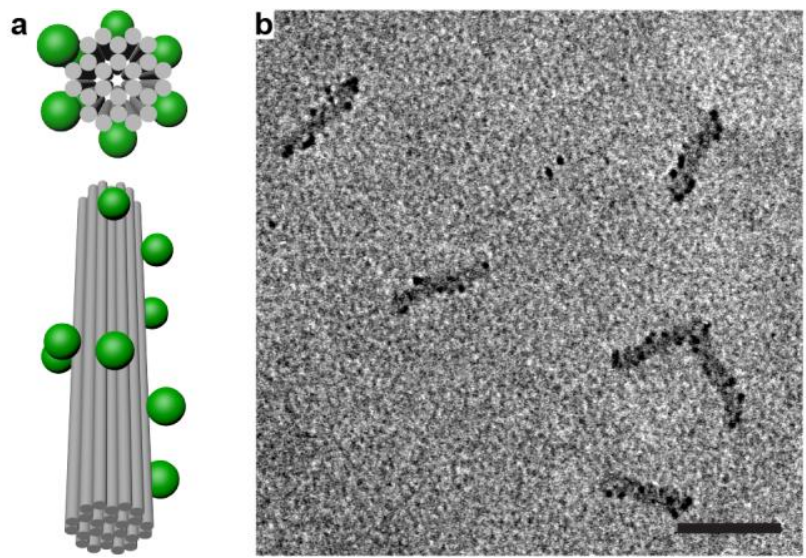

Figure 4. QDs assembled into chiral (here left-handed) helices. (a) Top and side view of the chiral QD assemblies on a 24-HB DNA origami; (b) TEM image of unstained 24-HB with helical assemblies of CdSeS/ZnS particles. Scale bar: $100 \mathrm{~nm}$.

\section{Conclusions}

With our simple method, we realized stable DNA functionalization of ZnS-shelled QDs. By attaching PTO-DNA to a newly-grown ZnS shell, a simple conjugation is established that ensures solubility even at high $\mathrm{Mg}^{2+}$ or $\mathrm{Na}^{+}$concentrations, allowing for site-specific positioning of these QDs on DNA origami templates. To recapitulate the threefold challenge mentioned above-reliable DNA conjugation to QDs, spatial assembly of these QDs, and optical characterization-we here offered new and simple ways to overcome the first challenge. We also obtained satisfactory assembly yields of particle dimers with defined distances and helical QD arrangements (overcoming the second challenge). To improve optical signals that would allow for optical analysis, several issues need to be addressed in future research. For one, the success of QD stabilization may critically depend on the used DNA sequence that interacts with the surface of the QDs. Also, the integration of functional chemistry groups, e.g., azides, alkynes, or multidentate thiol ligands, into the DNA strands could protect the QDs effectively through robust chemistry. To then observe the intricate behavior of coupled quantum emitter systems, QDs with outstanding optical properties will be required. Ultimately, DNA-based QD assembly in complex geometries will offer the possibility to probe fundamental interactions, such as exciton-exciton interactions or, for example, frustrated spin systems [56-62].

Supplementary Materials: The following figures are available online at http:/ / www.mdpi.com/2079-4991/9/ 3/339/s1, Figure S1: Transmission electron microscopy (TEM) images for CdSe/CdS/ZnS quantum dots (QDs) encapsulated in amphiphilic polymers, Figure S2: TEM images for PTO-DNA functionalized CdSeS/ZnS QDs incubated for different times, Figure S3: QD size distribution analysis with ImageJ, Figure S4: Size distribution of QDs and QDs incubated for different times, Figure S5: Agarose gel electrophoresis of QDs incubated for different times, Figure S6: TEM images for CdSe/CdS/ZnS QD dimer assemblies (spacing $50 \mathrm{~nm}$ ) on a one-layer rectangular DNA origami template before purification, Figure S7: Fluorescence intensity time trace of 10 different PTO-DNA-functionalized CdSe/CdS/ZnS QDs, Figure S8: Fluorescence intensity time trace of CdSe/CdS/ZnS QD dimers on a one-layer sheet DNA origami with two separations, 25 and $50 \mathrm{~nm}$, and Figure S9: Agarose gel electrophoresis of CdSeS/ZnS QDs (emission at 540 and $575 \mathrm{~nm}$ ) chiral assemblies on 24-HB origami.

Author Contributions: T.Z. and T.L. designed the research. T.Z. performed the experiments and analyzed the data. T.Z. and T.L. wrote the manuscript.

Funding: This research was generously funded by the Volkswagen Foundation and the Nanosystems Initiative Munich (NIM). T.Z. thanks the German Academic Exchange Service (DAAD) scholarship for supporting his PhD studies.

Acknowledgments: The authors thank Susanne Kempter for her help with the TEM imaging. The authors thank Andre Neumann, Jessica Lindlau, Alexander Högele, Francesca Nicoli, Mauricio Pilo-Pais, and Linh Nguyen for their helpful discussions. The authors thank the Efrat Lifshitz group at Technion-Israel Institute of Technology for providing the CdSe/CdS/ZnS quantum dots.

Conflicts of Interest: The authors declare no conflict of interest. 


\section{References}

1. Resch-Genger, U.; Grabolle, M.; Cavaliere-Jaricot, S.; Nitschke, R.; Nann, T. Quantum dots versus organic dyes as fluorescent labels. Nat. Methods 2008, 5, 763-775. [CrossRef] [PubMed]

2. Alivisatos, A.P. Semiconductor clusters, nanocrystals, and quantum dots. Science 1996, $271,933-937$. [CrossRef]

3. Smith, A.M.; Nie, S. Semiconductor nanocrystals: Structure, properties, and band gap engineering. Acc. Chem. Res. 2010, 43, 190-200. [CrossRef] [PubMed]

4. Pietryga, J.M.; Park, Y.-S.; Lim, J.; Fidler, A.F.; Bae, W.K.; Brovelli, S.; Klimov, V.I. Spectroscopic and Device Aspects of Nanocrystal Quantum Dots. Chem. Rev. 2016, 116, 10513-10622. [CrossRef] [PubMed]

5. Kagan, C.R.; Lifshitz, E.; Sargent, E.H.; Talapin, D.V. Building devices from colloidal quantum dots. Science 2016, 353, aac5523. [CrossRef] [PubMed]

6. Derfus, A.M.; Chan, W.C.W.; Bhatia, S.N. Probing the Cytotoxicity of Semiconductor Quantum Dots. Nano Lett. 2004, 4, 11-18. [CrossRef] [PubMed]

7. Kirchner, C.; Liedl, T.; Kudera, S.; Pellegrino, T.; Muñoz Javier, A.; Gaub, H.E.; Stölzle, S.; Fertig, N.; Parak, W.J. Cytotoxicity of Colloidal CdSe and CdSe/ZnS Nanoparticles. Nano Lett. 2005, 5, 331-338. [CrossRef] [PubMed]

8. Smith, A.M.; Ruan, G.; Rhyner, M.N.; Nie, S. Engineering Luminescent Quantum Dots for In Vivo Molecular and Cellular Imaging. Ann. Biomed. Eng. 2006, 34, 3-14. [CrossRef] [PubMed]

9. Medintz, I.L.; Uyeda, H.T.; Goldman, E.R.; Mattoussi, H. Quantum dot bioconjugates for imaging, labelling and sensing. Nat. Mater. 2005, 4, 435-446. [CrossRef] [PubMed]

10. Michalet, X.; Pinaud, F.F.; Bentolila, L.A.; Tsay, J.M.; Doose, S.; Li, J.J.; Sundaresan, G.; Wu, A.M.; Gambhir, S.S.; Weiss, S. Quantum Dots for Live Cells, in Vivo Imaging, and Diagnostics. Science 2005, 307, 538-544. [CrossRef] [PubMed]

11. Kairdolf, B.A.; Smith, A.M.; Stokes, T.H.; Wang, M.D.; Young, A.N.; Nie, S. Semiconductor Quantum Dots for Bioimaging and Biodiagnostic Applications. Annu. Rev. Anal. Chem. 2013, 6, 143-162. [CrossRef] [PubMed]

12. Dai, X.; Zhang, Z.; Jin, Y.; Niu, Y.; Cao, H.; Liang, X.; Chen, L.; Wang, J.; Peng, X. Solution-processed, high-performance light-emitting diodes based on quantum dots. Nature 2014, 515, 96-99. [CrossRef] [PubMed]

13. Dai, X.; Deng, Y.; Peng, X.; Jin, Y. Quantum-Dot Light-Emitting Diodes for Large-Area Displays: Towards the Dawn of Commercialization. Adv. Mater. 2017, 29, 1607022. [CrossRef] [PubMed]

14. Murray, C.B.; Norris, D.J.; Bawendi, M.G. Synthesis and Characterization of Nearly Monodisperse CdE $(\mathrm{E}=\mathrm{S}, \mathrm{Se}, \mathrm{Te})$ Semiconductor Nanocrystallites. J. Am. Chem. Soc. 1993, 115, 8706-8715. [CrossRef]

15. Beberwyck, B.J.; Surendranath, Y.; Alivisatos, A.P. Cation exchange: A versatile tool for nanomaterials synthesis. J. Phys. Chem. C 2013, 117, 19759-19770. [CrossRef]

16. Peng, X.; Manna, L.; Yang, W.; Wickham, J.; Scher, E.; Kadavanich, A.; Alivisatos, A.P. Shape control of CdSe nanocrystals. Nature 2000, 404, 59-61. [CrossRef] [PubMed]

17. Kim, S.; Fisher, B.; Eisler, H.J.; Bawendi, M. Type-II quantum dots: CdTe/CdSe (core/shell) and CdSe/ZnTe (core/shell) heterostructures. J. Am. Chem. Soc. 2003, 125, 11466-11467. [CrossRef] [PubMed]

18. Yin, Y.; Alivisatos, A.P. Colloidal nanocrystal synthesis and the organic-inorganic interface. Nature 2005, 437, 664-670. [CrossRef] [PubMed]

19. Pu, C.; Qin, H.; Gao, Y.; Zhou, J.; Wang, P.; Peng, X. Synthetic Control of Exciton Behavior in Colloidal Quantum Dots. J. Am. Chem. Soc. 2017, 139, 3302-3311. [CrossRef] [PubMed]

20. Govorov, O. Spin and energy transfer in nanocrystals without tunneling. Phys. Rev. B 2003, 68, 075315. [CrossRef]

21. Ouyang, M.; Awschalom, D.D. Coherent spin transfer between molecularly bridged quantum dots. Science 2003, 301, 1074-1078. [CrossRef] [PubMed]

22. Govorov, A.O.; Bryant, G.W.; Zhang, W.; Skeini, T.; Lee, J.; Kotov, N.A.; Slocik, J.M.; Naik, R.R. Exciton-plasmon interaction and hybrid excitons in semiconductor-metal nanoparticle assemblies. Nano Lett. 2006, 6, 984-994. [CrossRef]

23. Lee, J.J.; Hernandez, P.; Lee, J.J.; Govorov, A.O.; Kotov, N.A. Exciton-plasmon interactions in molecular spring assemblies of nanowires and wavelength-based protein detection. Nat. Mater. 2007, 6, 291-295. [CrossRef] [PubMed] 
24. Stangl, J.; Holý, V.; Bauer, G. Structural properties of self-organized semiconductor nanostructures. Rev. Mod. Phys. 2004, 76, 725-783. [CrossRef]

25. Ye, X.; Chen, J.; Engel, M.; Millan, J.A.; Li, W.; Qi, L.; Xing, G.; Collins, J.E.; Kagan, C.R.; Li, J.; et al. Competition of shape and interaction patchiness for self-assembling nanoplates. Nat. Chem. 2013, 5, 466-473. [CrossRef] [PubMed]

26. Kalsin, A.M.; Fialkowski, M.; Paszewski, M.; Smoukov, S.K.; Bishop, K.J.M.; Grzybowski, B.A. Electrostatic self-assembly of binary nanoparticle crystals with a diamond-like lattice. Science 2006, 312, 420-424. [CrossRef] [PubMed]

27. Lin, Y.; Böker, A.; He, J.; Sill, K.; Xiang, H.; Abetz, C.; Li, X.; Wang, J.; Emrick, T.; Long, S.; et al. Self-directed self-assembly of nanoparticle/copolymer mixtures. Nature 2005, 434, 55-59. [CrossRef] [PubMed]

28. Ye, X.; Zhu, C.; Ercius, P.; Raja, S.N.; He, B.; Jones, M.R.; Hauwiller, M.R.; Liu, Y.; Xu, T.; Alivisatos, A.P. Structural diversity in binary superlattices self-assembled from polymer-grafted nanocrystals. Nat. Commun. 2015, 6, 10052. [CrossRef] [PubMed]

29. Stevens, M.M.; Flynn, N.T.; Wang, C.; Tirrell, D.A.; Langer, R. Coiled-coil peptide-based assembly of gold nanoparticles. Adv. Mater. 2004, 16, 915-918. [CrossRef]

30. Kostiainen, M.A.; Hiekkataipale, P.; Laiho, A.; Lemieux, V.; Seitsonen, J.; Ruokolainen, J.; Ceci, P. Electrostatic assembly of binary nanoparticle superlattices using protein cages. Nat. Nanotechnol. 2013, 8, 52-56. [CrossRef] [PubMed]

31. Nykypanchuk, D.; Maye, M.M.; Van Der Lelie, D.; Gang, O. DNA-guided crystallization of colloidal nanoparticles. Nature 2008, 451, 549-552. [CrossRef] [PubMed]

32. Macfarlane, R.J.; Lee, B.; Jones, M.R.; Harris, N.; Schatz, G.C.; Mirkin, C.A. Nanoparticle Superlattice Engineering with DNA. Science 2011, 334, 204-208. [CrossRef] [PubMed]

33. Jones, M.R.; Seeman, N.C.; Mirkin, C.A. Programmable materials and the nature of the DNA bond. Science 2015, 347, 1260901. [CrossRef] [PubMed]

34. Seeman, N.C.; Sleiman, H.F. DNA nanotechnology. Nat. Rev. Mater. 2017, 3, 17068. [CrossRef]

35. Mitchell, G.P.; Mirkin, C.A.; Letsinger, R.L. Programmed assembly of DNA functionalized quantum dots. J. Am. Chem. Soc. 1999, 121, 8122-8123. [CrossRef]

36. Farlow, J.; Seo, D.; Broaders, K.E.; Taylor, M.J.; Gartner, Z.J.; Jun, Y.W. Formation of targeted monovalent quantum dots by steric exclusion. Nat. Methods 2013, 10, 1203-1205. [CrossRef] [PubMed]

37. Shen, J.; Tang, Q.; Li, L.; Li, J.; Zuo, X.; Qu, X.; Pei, H.; Wang, L.; Fan, C. Valence-Engineering of Quantum Dots Using Programmable DNA Scaffolds. Angew. Chem. Int. Ed. 2017, 56, 16077-16081. [CrossRef] [PubMed]

38. Sun, D.; Gang, O. DNA-Functionalized Quantum Dots: Fabrication, Structural, and Physicochemical Properties. Langmuir 2013, 29, 7038-7046. [CrossRef] [PubMed]

39. Bui, H.; Onodera, C.; Kidwell, C.; Tan, Y.; Graugnard, E.; Kuang, W.; Lee, J.; Knowlton, W.B.; Yurke, B.; Hughes, W.L. Programmable Periodicity of Quantum Dot Arrays with DNA Origami Nanotubes. Nano Lett. 2010, 10, 3367-3372. [CrossRef] [PubMed]

40. Takabayashi, S.; Klein, W.P.; Onodera, C.; Rapp, B.; Flores-Estrada, J.; Lindau, E.; Snowball, L.; Sam, J.T.; Padilla, J.E.; Lee, J.; et al. High precision and high yield fabrication of dense nanoparticle arrays onto DNA origami at statistically independent binding sites. Nanoscale 2014, 6, 13928-13938. [CrossRef] [PubMed]

41. Parak, W.J.; Gerion, D.; Zanchet, D.; Woerz, A.S.; Pellegrino, T.; Micheel, C.; Williams, S.C.; Seitz, M.; Bruehl, R.E.; Bryant, Z.; et al. Conjugation of DNA to silanized colloidal semiconductor nanocrystalline quantum dots. Chem. Mater. 2002, 14, 2113-2119. [CrossRef]

42. Lin, C.-A.J.; Sperling, R.A.; Li, J.K.; Yang, T.-Y.; Li, P.-Y.; Zanella, M.; Chang, W.H.; Parak, W.J. Design of an Amphiphilic Polymer for Nanoparticle Coating and Functionalization. Small 2008, 4, 334-341. [CrossRef] [PubMed]

43. Sperling, R.A.; Parak, W.J. Surface modification, functionalization and bioconjugation of colloidal Inorganic nanoparticles. Philos. Trans. R. Soc. A 2010, 368, 1333-1383. [CrossRef] [PubMed]

44. Wang, Q.; Liu, Y.; Ke, Y.; Yan, H. Quantum Dot Bioconjugation during Core-Shell Synthesis. Angezw. Chem. 2008, 120, 322-325. [CrossRef]

45. Tikhomirov, G.; Hoogland, S.; Lee, P.E.; Fischer, A.; Sargent, E.H.; Kelley, S.O. DNA-based programming of quantum dot valency, self-assembly and luminescence. Nat. Nanotechnol. 2011, 6, 485-490. [CrossRef] [PubMed] 
46. Deng, Z.; Samanta, A.; Nangreave, J.; Yan, H.; Liu, Y. Robust DNA-functionalized core/shell quantum dots with fluorescent emission spanning from UV-vis to near-IR and compatible with DNA-directed self-assembly. J. Am. Chem. Soc. 2012, 134, 17424-17427. [CrossRef] [PubMed]

47. Samanta, A.; Zhou, Y.; Zou, S.; Yan, H.; Liu, Y. Fluorescence quenching of quantum dots by gold nanoparticles: A potential long range spectroscopic ruler. Nano Lett. 2014, 14, 5052-5057. [CrossRef] [PubMed]

48. Vaxenburg, R.; Rodina, A.; Lifshitz, E.; Efros, A.L. Biexciton Auger Recombination in CdSe/CdS Core/Shell Semiconductor Nanocrystals. Nano Lett. 2016, 16, 2503-2511. [CrossRef] [PubMed]

49. Nickels, P.C.; Ke, Y.; Jungmann, R.; Smith, D.M.; Leichsenring, M.; Shih, W.M.; Liedl, T.; Högberg, B. DNA Origami Structures Directly Assembled from Intact Bacteriophages. Small 2014, 10, 1765-1769. [CrossRef] [PubMed]

50. Samanta, A.; Deng, Z.; Liu, Y.; Yan, H. A perspective on functionalizing colloidal quantum dots with DNA. Nano Res. 2013, 6, 853-870. [CrossRef]

51. Douglas, S.M.; Marblestone, A.H.; Teerapittayanon, S.; Vazquez, A.; Church, G.M.; Shih, W.M. Rapid prototyping of 3D DNA-origami shapes with caDNAno. Nucleic Acids Res. 2009, 37, 5001-5006. [CrossRef] [PubMed]

52. Deng, Z.; Schulz, O.; Lin, S.; Ding, B.; Liu, X.; Wei, X.; Ros, R.; Yan, H.; Liu, Y. Aqueous Synthesis of Zinc Blende CdTe/CdS Magic-Core/Thick-Shell Tetrahedral-Shaped Nanocrystals with Emission Tunable to Near-Infrared. J. Am. Chem. Soc. 2010, 132, 5592-5593. [CrossRef] [PubMed]

53. Kim, D.-N.; Kilchherr, F.; Dietz, H.; Bathe, M. Quantitative prediction of 3D solution shape and flexibility of nucleic acid nanostructures. Nucleic Acids Res. 2012, 40, 2862-2868. [CrossRef] [PubMed]

54. Kuzyk, A.; Schreiber, R.; Fan, Z.; Pardatscher, G.; Roller, E.-M.M.; Högele, A.; Simmel, F.C.; Govorov, A.O.; Liedl, T. DNA-based self-assembly of chiral plasmonic nanostructures with tailored optical response. Nature 2012, 483, 311-314. [CrossRef] [PubMed]

55. Efros, A.L.; Nesbitt, D.J. Origin and control of blinking in quantum dots. Nat. Nanotechnol. 2016, 11, 661-671. [CrossRef] [PubMed]

56. Empedocles, S.A.; Neuhauser, R.; Bawendi, M.G. Three-dimensional orientation measurements of symmetric single chromophores using polarization microscopy. Nature 1999, 399, 126-130. [CrossRef]

57. Lethiec, C.; Laverdant, J.; Vallon, H.; Javaux, C.; Dubertret, B.; Frigerio, J.M.; Schwob, C.; Coolen, L.; Maître, A. Measurement of three-dimensional dipole orientation of a single fluorescent nanoemitter by emission polarization analysis. Phys. Rev. X 2014, 4, 021037. [CrossRef]

58. Hu, J.; Li, L.; Yang, W.; Manna, L.; Wang, L.; Alivisatos, A.P. Linearly Polarized Emission from Colloidal Semiconductor Quantum Rods. Science 2001, 292, 2060-2063. [CrossRef] [PubMed]

59. Li, L.; Alivisatos, A.P. Origin and Scaling of the Permanent Dipole Moment in CdSe Nanorods. Phys. Rev. Lett. 2003, 90, 097402. [CrossRef] [PubMed]

60. Shabaev, A.; Efros, A.L. 1D exciton spectroscopy of semiconductor nanorods. Nano Lett. 2004, 4, 1821-1825. [CrossRef]

61. Eshet, H.; Grünwald, M.; Rabani, E. The Electronic Structure of CdSe/CdS Core/Shell Seeded Nanorods: Type-I or Quasi-Type-II? Nano Lett. 2013, 13, 5880-5885. [CrossRef] [PubMed]

62. Wu, K.; Hill, L.J.; Chen, J.; McBride, J.R.; Pavlopolous, N.G.; Richey, N.E.; Pyun, J.; Lian, T. Universal Length Dependence of Rod-to-Seed Exciton Localization Efficiency in Type I and Quasi-Type II CdSe@CdS Nanorods. ACS Nano 2015, 9, 4591-4599. [CrossRef] [PubMed]

(C) 2019 by the authors. Licensee MDPI, Basel, Switzerland. This article is an open access article distributed under the terms and conditions of the Creative Commons Attribution (CC BY) license (http:/ / creativecommons.org/licenses/by/4.0/). 